\title{
Analysis of Working Capital Sources on Firm Innovation, and Labor Productivity among Manufacturing Firms in DR Congo
}

\author{
Michael Asiedu', Sabi Couscous Mouhamadou Nazirou'², Dalal Subhi Mousa², \\ Soazafy Joyce Sabrina², Asamoah Achia Rosemary ${ }^{3}$ \\ ${ }^{1}$ School of Finance, Zhongnan University of Economics and Law, Wuhan, China \\ ${ }^{2}$ School of Economics, Zhongnan University of Economics and Law, Wuhan, China \\ ${ }^{3}$ Law School, Zhongnan University of Economics and Law, Wuhan, China \\ Email: asiedum@stu.zuel.edu.cn, dalalmusa@gmail.com, naziroucouscous@gmail.com, soajoyce23@yahoo.fr, \\ akyiaaasamoah@yahoo.com
}

How to cite this paper: Asiedu, M., Nazirou, S. C. M., Mousa, D. S., Sabrina, S. J., \& Rosemary, A. A. (2021). Analysis of Working Capital Sources on Firm Innovation, and Labor Productivity among Manufacturing Firms in DR Congo. Journal of Financial Risk Management, 10, 200-223. https://doi.org/10.4236/jfrm.2021.102012

Received: April 11, 2021

Accepted: June 27, 2021

Published: June 30, 2021

Copyright $\odot 2021$ by author(s) and Scientific Research Publishing Inc. This work is licensed under the Creative Commons Attribution International License (CC BY 4.0).

http://creativecommons.org/licenses/by/4.0/

\begin{abstract}
This study identifies the relevant sources of firm working capital and examines their interrelationship with innovation activities and labor productivity among 529 manufacturing firms in DR Congo using the 2013 Enterprise Survey Database. We identify external funding sources as the most crucial funding source for innovation activities among manufacturing firms in DR Congo. We further establish a transmission mechanism of firm innovation through the availability of an active line of credit on firm productivity. Productive firms rely mainly on external funding for their innovation activities. We also show by the technique of propensity score matching, that the Average Treatment Effect (ATE) of R\&D spending is positive and statistically significant at $5 \%$. R\&D spending impacts labour productivity by nearly $53 \%$ higher for firms with $R \& D$ spending in the last three (3) years than their counterparts. Similarly, the Average Treatment Effect on the Treated (ATET) is positive and statistically significant at $5 \%$. We report an overwhelming $112 \%$ positive effect of $R \& D$ spending in the last three (3) years on firm productivity for the treatment group. Further analysis of the business environment shows that the absence of adequately educated labor force, obstacles associated with access to land, illegal activities of competitors, political instability, corruption, and obstacles encountered by firms from the courts and legal systems negatively affects firm productivity. Our key policy recommendation includes: 1) the need for an immediate robust and efficient financial market to channel funding to manufacturing firms, and 2) firm innovation should be the underlying factor in capital allocation.
\end{abstract}




\section{Keywords}

Firm Innovation, Productivity, Propensity Score Matching, Research and Development, Working Capital

\section{Introduction}

Investment in $\mathrm{R} \& \mathrm{D}$ (innovation activities) is often considered intangible capital investment, and financial institutions usually consider it very risky and unwilling to commit to it. Firms engaging in $R \& D$ therefore usually find it very challenging to access external funding beyond their internally generated funds as a result of the general complexities and challenges associated with R\&D outcomes (Hall, 1992; Hall \& Lerner, 2010). The situation even gets worse in Africa due to the absence of robust financial systems and markets to fund R\&D activities even though they generate positive and spillovers effects. But more importantly, endogenous growth models identify technological advancement (innovation) rather capital accumulation as the main driver of economic growth (Romer, 1990; Solow, 1957; Aghion \& Howitt, 1990).

A number of theoretical and empirical studies including (Fazzari \& Petersen, 1993; Fudenberg \& Tirole, 1983; Nikolov et al., 2021; Clementi \& Hopenhayn, 2006) have examined the effects of working capital sources on firm investment and growth potentials. Their findings have not only reinforced earlier propositions about innovation and investment but also proven to have important implications for firm value. The techniques of financing firms and capital budgeting have been the mainstay of corporate finance to overcome financing constraints. As pointed out by (Modigliani \& Miller, 1958), in an investment environment where capital is used to acquire different classes of assets yielding uncertain returns; and more so capital can be acquired from different sources, ranging from debt instruments to equity. Hence in a frictionless financial system, firms access to external funding will not be crucial to their value and performance. According to (Fazzari \& Petersen, 1993), most of the empirical studies have been conducted along 1) the reduced form regression and 2) by the Euler equation yet both approaches have their practical limitations including the fact that, a positive cash flow effect may be observed because cash flow proxies investment rather than providing evidence for finance constraints. In addition, most of the existing literature are on developed economies, while developing economies are largely missing out (Crisóstomo et al., 2014).

This study, however, examines the interrelationship between the sources of firm working capital on firm innovation and labour productivity among manufacturing firms in DR Congo. To the best of our knowledge, no empirical study prevails specifically to DR Congo that explores the sensitivity of the interrelationship between working capital, firm innovation, and labour productivity. The uniqueness of the financial ecosystem and the general structure of the economy 
of DR Congo, for instance the illiquidity and imperfections of the financial system such as information asymmetries, adverse selection and moral hazards and the absence of a systematic study on how working capital sources (internal and external) influence firm innovation and productivity is very critical.

We identify external funding sources as the most crucial funding source of innovation activities among manufacturing firms in DR Congo. We further establish a transmission mechanism of firm innovation through the availability of an active line of credit on firm productivity. Productive firms rely mainly on external funding for their innovation activities. We also show by the technique of propensity score matching, that the Average Treatment Effect (ATE) of R\&D spending is positive and statistically significant at $5 \%$. R\&D spending impacts labour productivity by nearly $53 \%$ higher for firms that spent on research and development (R\&D) in the last three (3) than their counterparts. Similarly, the Average Treatment Effect on the Treated (ATET) is positive and statistically significant at $5 \%$. We report an overwhelming $112 \%$ positive effect of R\&D spending in the last three (3) years on firm productivity of the treatment group. Further analysis of the business environment establishes that the absence of adequately educated labor force, obstacles associated with access to land, activities of competitors within the informal sector, political instability, corruption and obstacles encountered by firms from the courts and legal systems negatively affects firm productivity. The rest of this arranged as follows; section 2 is the literature review and section three (3) discusses the data source of study. Section four (4) discusses the methodology of the study, whilst the variables are defined in section five (5). The empirical results and conclusion are discussed in section six (6) and seven (7) respectively.

\section{Literature Review}

Though significant progress has been achieved since (Solow, 1957), in underscoring the key drivers of global economic growth, the transmission mechanism through which the effects are channeled remains quiet opaque especially in less developed countries with less structured and large informal sectors. Both theoretical and empirical researchers have accepted that technological advancement is critical for economic growth, however, the existing literature is not clear about how technological advancement is affected by the scarcity of finance and the weak financial systems in less developed countries. Earlier studies including (Baumol, 2002) and (Aghion et al., 2005) examined the macro level effect of technological advancement, however, were based on the study of large, publicly traded firms in advanced economies with very limited focus on developing economies. Some studies have however, been conducted in selected low-income countries in recent times. For instance, in a study involving 418 manufacturing firms in Sub-Sahara Africa, (Barasa et al., 2017) found that internal R\&D, and foreign technology negatively affects technical efficiency of the firm. However, a combination of foreign technology and internal R\&D, foreign technology and 
HCD improves each other's impact on the technical efficiency of the firm. In a sample of 1157 manufacturing firms in Sub-Saharan Africa, (Adu-Danso \& Abbey, 2020) examined the effect of foreign ownership on technological innovation amongst manufacturing firms in Africa. The study established that foreign owned firms are not likely to introduce product innovation. They however, did not find a significant relationship between process innovation and firm foreign ownership. (Corbett et al., 2005) found that firms experience significant abnormal improvements in financial performance after their first ISO 900 certification among US manufacturing firms. However, three years after acquiring an ISO certification, they find the firms not to exhibit significant abnormal performance under all control-group specification. (Kannebley et al., 2010) affirmed that technologically innovative firms produce positive and significant impact on firm value among Brazilian firms. Innovative firms exhibited 10.8 - 12.5 percentage points higher growth in employment, 18.1 - 21.7 percentage points higher growth on net revenue, $10.8-11.9$ percentage points higher growth on labor productivity and 19.9 - 24.3 percentage points higher growth on capital productivity, relative to the average growth of non-innovating firms. (Brown \& Guzmán, 2014) examined 2078 Mexican manufacturing firms. They found that manufacturing firms with a higher innovation tendency are the largest firms, with high technological capacity and market share. In addition, innovation, labour remunerations and capital intensity have a substantial effect on labour productivity and at a lower market share, foreign direct investment, and total quality control. On the analysis of firm innovation and the differences between family and non-family firms, (Classen et al., 2014) observed significant differences at each stage of the innovation process using the community innovation survey on 2087 German small and medium sized firms. They observed that, family SMEs perform better than non-family SMEs in terms of process innovation outcomes after controlling for innovation investment. However, non-family firms were recorded to perform better than family SMEs with regards to labour productivity. (Wadho \& Chaudhry, 2018) find that increased labour productivity and labour productivity growth are directly linked to firm innovation among textile and apparel manufacturing firms in Pakistan. For instance, a 10\% rise in innovation sales per worker accounts for more than a $10 \%$ increase in labour productivity and labour productivity growth. (Díaz-Chao et al., 2015) also established an indirect association between co-innovation and productivity in firms that undertake international expansion. They identify wage as the main determinant of labour productivity in a sample of 464 SMEs in Spain. However, in sharp contrast to the evidence regarding larger firms, the productivity of small local firms is not directly affected by co-innovation. Evidence based on OECD database shows that very high rates of R\&D investment and high corporate taxes do not accelerate labour productivity across nations. Accordingly, (Coccia, 2018) explained that R\&D intensity of about $2.5 \%$ and corporate tax rate of $3.1 \%$ of GDP ideally maximizes labour productivity. Evidence on finance constraints on investment is 
provided by (Fazzari \& Petersen, 1993). They found that, in a fixed-investment regression, the effect of endogenous working capital investment is negative. This is a consequence of working capital competing with fixed investment for the limited available finance. (Kirner et al., 2009) analysed product and process innovation among 1663 low-technology manufacturing firms in Germany. They found evidence to the effect that low-technology manufacturing firms are less productive than their medium and high-technology counterparts.

(Cassoni \& Ramada-Sarasola, 2010) suggest that inadequate investment in knowledge capital accounts for the low economic growth in the case of Uruguay. Returns on innovation among manufacturing firms in Uruguay, were found to be significant and positively accelerating labour productivity gains. They however, observed that, high internal efficiency is crucial to the firms urge to innovate and magnitude of expansion. In a related study involving $170 \mathrm{UK}$ firms, (Wakelin, 2001) employ a Cobb-Douglas function and incorporated R\&D intensity. The study established a positive and significant effect for internal R\&D spending on firm productivity growth. Firm innovation history and the sector or industry in which the operates were found to be crucial factors determining the returns of R\&D. (Janz et al., 2003) contributed to the body for literature on innovation-productivity through the application of the knowledge of production function that details the inter-connectedness between firm innovation and productivity. Their results were found to be same across firms in Germany and Sweden for knowledge intensive manufacturing firms. (Gallego et al., 2015) argued that, regardless of industry, a firms' propensity to innovate increases when there is huge investment in $\mathrm{R} \& \mathrm{D}$ and with large firms. Labour productivity is also accelerated with the introduction of innovations, such that the higher the likelihood of implementing innovation activities, the higher the intensity of innovation investment. In a related study using firm level data from the Korea Innovation Survey on Korean manufacturing companies in 2002, (Lee \& Kang, 2007) find evidence suggesting that, innovation type matters in firm productivity growth. However, process innovation is suggested to trigger higher productivity than product innovation in the short run.

We find from the above related literature that, the inability of some countries to achieve sustained and high levels of economic growth cannot be entirely accounted for by external shocks, weak institutional structures, and weak levels of human and capital accumulation. While there are extensive studies on innovation and technological advancement, very few studies have focused on the structure of working capital on firm innovation and labour productivity.

\section{Data Source and Descriptive Statistics}

The data sources and variable descriptions use in this empirical analysis are discussed in this section. This study employs firm-level data of manufacturing firms in DR Congo from the World Bank's Enterprise Survey Indicator Database, 
https://www.enterprisesurveys.org conducted in 2013. There is a total of 529 firms across 24 industries.

The Enterprise Survey Data, entails a set of questions on firm innovation, posed to firm owners seeking answers as to whether they engaged in specific innovative activities. These questions include the number of resources invested in $\mathrm{R} \& \mathrm{D}$ and extends it to questions on the firm's innovation activities to the (New Product, new or significantly improved methods of manufacturing products (New Technology), new or significantly improved logistical or business support processes (H3), new or significantly improved organizational structures or management practices ( $\mathrm{H} 4 \mathrm{a})$, introduced new or significantly improved marketing methods (H4b), did this establishment spend on formal research and development activities, either in-house or contracted with other companies (H5), did this establishment give employees some time to innovate or try out a new approach or new idea about the products or services (H6), business process, firm management, or marketing (H7), and other related innovation questions such as whether the firm has ISO certification (H8). (Ayyagari et al., 2011) argue that innovation in countries located far inside their production possibility frontier might mostly be imitating and adopting instead of inventing. This study, however, extends its focus to all the set of questions related to firm innovation rather than just focusing on only process and product innovation as adopted in most empirical studies. Most importantly, we acknowledge that our sample consists of firms in a less developed country (DR Congo) and are most likely operating within its technological possibility frontier, although (Gorodnichenko et al., 2010) also argued that using $R \& D$ expenditure as a basis of innovation may be inappropriate. However, we rely on the fact that R\&D most often generates all innovations, and firms in less developed countries should not just be confined to imitation or borrowing innovative ideas.

The summary statistics of the key variables of interest are presented in Table 2. The mean firm age (lnFirmage) is 2.081 years whilst the maximum firm is 4.443 years old, and the minimum age is zero (which means the firm was less than a year old at the time of the survey). The mean value of firm productivity is 14.4. The average working experience of a firm manager is 14 years, and the maximum working experience is 66 years. The pairwise correlation matrix is also reported in Table 3 . We find that even though most of the correlation coefficients are statistically significant at $5 \%$, they are mostly weakly correlated.

\section{Methodology}

The empirical analysis of this study is developed on the latent regression of the form:

$$
y^{*}=x^{\prime} \beta+\varepsilon
$$

where $y^{*}$ is an unobservable index variable, $x$ is a vector of explanatory variables, $\beta$ is a vector of parameters, and $\varepsilon$ is an error term (see, for instance, (Liu, 2015), chap. 3 and 11). 
For the binary case (Section 4.1), $y=1$ (i.e., innovative firm) if $y^{*}>0$ and $y=0$ (i.e., non-innovative firm) if $y^{*} \leq 0$. For the ordered case where $y$ denotes a firm innovation level, which ranges from 1 to $J$.

$y=1$ if $y^{*} \leq \alpha_{1} ; y=2$ if $\alpha_{1}<y^{*} \leq \alpha_{2}, \cdots, y=J$ if $\alpha_{J-1} \leq y^{*}$ such that $\alpha_{1}<\alpha_{2}<\cdots<\alpha_{J-1}$ are the threshold parameters or cutoffs.

For binary data, the odds ratio of a logit model is given by

$$
\frac{p}{1-p}=\frac{1+\mathrm{e}^{x / \beta}}{1+\mathrm{e}^{-x / \beta}}=\mathrm{e}^{x / \beta}
$$

The odds ratio represents the probability of success or having an event, $p$, to the probability of failure or not having an event $(1-p)$.

By taking natural logarithm of both sides of Equation (2), one obtains the logistic regression model

$$
\ln \left(\frac{p}{1-p}\right)=x^{\prime} \beta=\beta_{1}+\beta_{2} x_{2}+\cdots+\beta_{k} x_{k}
$$

The empirical model to examine the relationship between firm productivity and firm innovation is formally expressed as bellow:

$$
\begin{aligned}
\left({\text { Productivity })_{i, j}=}\right. & \alpha+\beta_{1} \text { Firms size dummy }_{i, j}+\beta_{2}\left({\text { Firm Innovation })_{i, j}}\right. \\
& +\beta_{3} \text { nfFirmAGE }_{i, j}+\beta_{4} \text { Capacity Utilization }_{i, j} \\
& +\beta_{5}(i \text {. Ownership })_{i, j}+\beta_{6}(i . \text { Working Capital })_{i, j} \\
& +\beta_{7}(i . \text { Location size dummies })_{i, j, k} \\
& +\beta_{8}(i . \text { Industry dummies })_{i, j} \\
& +\beta_{9}(i \text {. Line of credit })_{i, j, k}+\varepsilon_{i, j}
\end{aligned}
$$

where $i=1, \cdots, 529$ firms and $J=1, \cdots, 24$ industries.

The study further employs Propensity Score Matching to examine the effect of $\mathrm{R} \& \mathrm{D}$ spending on firm productivity. Our treatment variable is $\mathrm{R} \& \mathrm{D}$ spending.

Treatment variables $(w)$ is R\&D spending.

Where $(w)=1$ denotes treatment and $(w)=0$ otherwise. Our treatment variable is $\mathrm{R} \& \mathrm{D}$ spending as defined in the Enterprise Survey Database for DR Congo.

Productivity $(y)$ is the outcome variable. We let $\left(y_{1}\right)$ denote outcome with treatment and $\left(y_{0}\right)$ denote outcome without treatment.

Covariates $(x)$ are Ln(Firm Age), Int. Certification, Exporter (\%), Private-dome Foreign Private, Government firms, Female ownership, Source of working capital, Line of Credit, Capacity Utilization, and Obstacle to Finance.

Our treatment variable is binary (i.e. 1 if the firm spent on $R \& D$, otherwise 0 ).

The expression $\left(y_{1}, y_{0}, w\right)$ is a random vector from the population. Following (Rosenbaum \& Rubin, 1983), we estimate the variable of interest, Average Treatment Effect (ATE) as $E\left(y_{1}-y_{0}\right)$; this expression expected effect of treatment on a randomly selected firm.

Another variable of interest is the Average Treatment Effect on the Treated (atet), formally expressed as $E\left(y_{1}-y_{0} \mid w=1\right)$. 
Average Treatment Effect (ate) $\equiv E\left(y_{1}-y_{0}\right)$

Average Treatment Effect on the Treated (atet) $\equiv E\left(y_{1}-y_{0} \mid w=1\right)$, we further estimate the average treatment effect of the untreated following the expression in Equation (3).

Average Treatment Effect on the Untreated (atu) $\equiv E\left(y_{1}-y_{0} \mid 1-w\right)$

The estimation of the three (3) treatment effects is further expanded by the introduction or conditioning of covariates $(x)$ listed above.

Average Treatment Effect (ate) $\equiv E\left(y_{1}-y_{0} \mid x\right)$

Average Treatment Effect on the Treated (atet) $\equiv E\left(y_{1}-y_{0} \mid x, w=1\right)$, we further estimate the average treatment effect of the untreated following the expression in Equation (3).

Average Treatment Effect on the Untreated (atu)

$\equiv E\left(y_{1}-y_{0} \mid x, 1-w\right) \equiv E\left(y_{1}-y_{0} \mid x, 1-e 7\right) \equiv E\left(y_{1}-y_{0} \mid x\right.$, noe 7$)$ and $\equiv E\left(y_{1}-y_{0} \mid x, 1-e 8\right) \equiv E\left(y_{1}-y_{0} \mid x\right.$, noe 8$)$.

\section{Definition and Description of Data}

This section of study presents the definition of variables, descriptive statistics, the pairwise correlation matrix and the Two-way measure of association between selected variables.

From our definition of variables in Table 1, there is total number of $529 \mathrm{ob}$ servations for all the variables. Exporter: exporter (exporter vs. non-exporters) has an average value of 1.206 and a maximum of 90 (meaning the firm with the highest percentage of exports as a percentage of its total national output); Top Manager experience; top managers experience (years) averages at 13.8 years; Firm Age (lnFirmage), also averages at 2.08 years to 4.44 years. The mean value for Private-domestic ownership (\%) 76.86. This rate means that most of the firms are predominantly private. Internal funds: internal funds for investment (\%) constitute $89.8 \%$ of the working capital sources of firms whilst the remaining $10.2 \%$ accounts for external working capital sources including funds borrowed from banks: bank finance for investment (\%); funds borrowed from non-bank financial: non-bank financial institutions finance for investment (\%), and Purchases on credit from suppliers: supplier credit financing (\%).

Pairwise correlations and two-way measure of association between selected variables.

The pairwise correlation matrix of the variables is reported above in Table 3. We find that all other variables are weakly correlated except the correlation between foreign private ownership and private domestic ownership is negative and highly correlated. Similarly, funds borrowed from banks and trade credit are negatively and highly correlated with internal funding sources of working capital.

\section{Two-Way Measure of Association between Selected Variables}

We measure the two-way association and the statistical independence between 1) Firm Size versus Product Innovation 2) Firm size versus Process Innovation 
3) Firm size versus Availability of Line of Credit 4) Firm size versus R\&D spending using Pearson chi-square and Cramer's V statistic. The resultant association and probabilities are reported in Tables 3-6.

Table 1. Definition of variables.

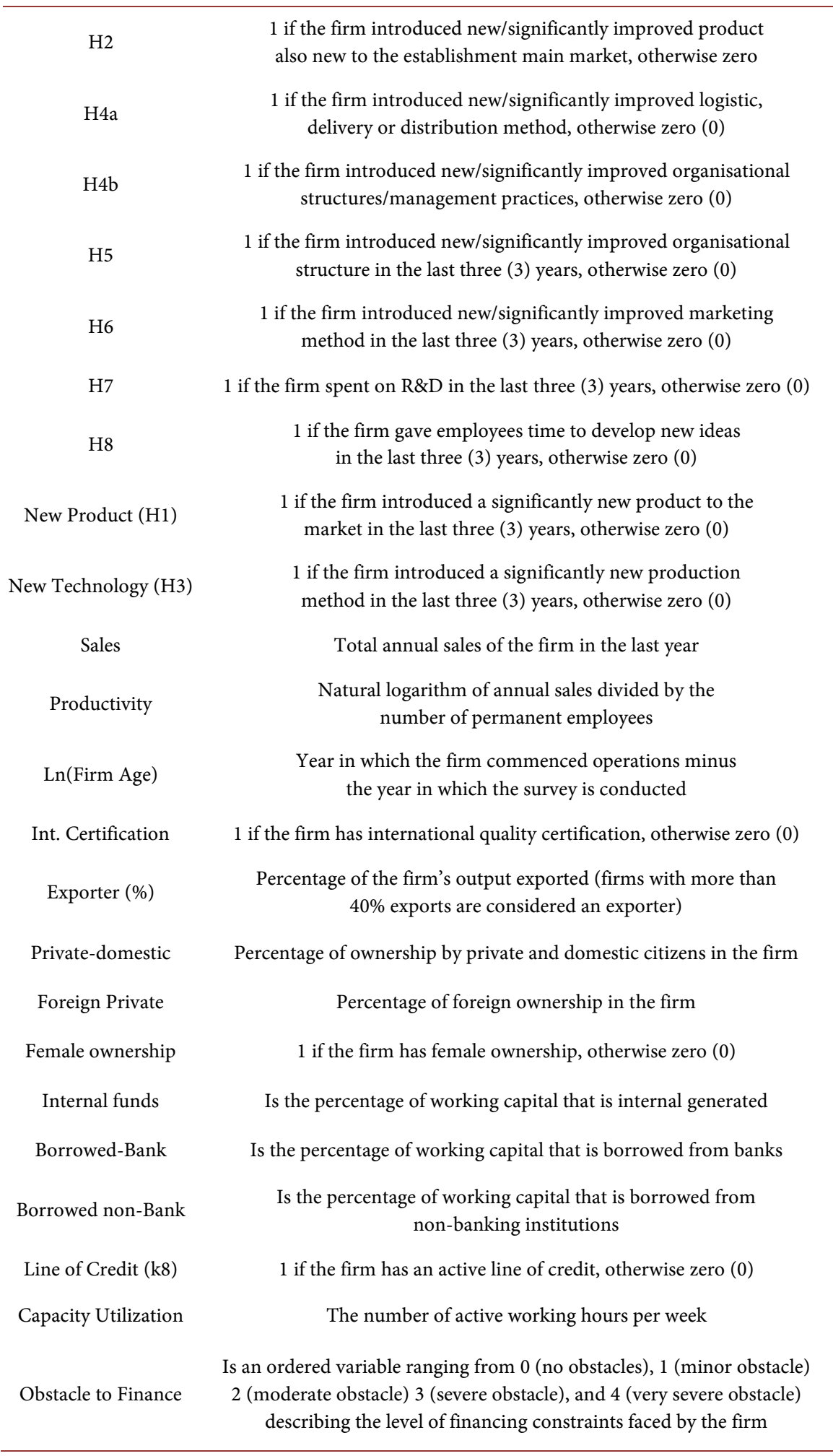


Table 2. Descriptive statistics.

\begin{tabular}{cccccc}
\hline Variable & Obs & Mean & Std. Dev. & Min & Max \\
\hline H1 & 529 & 0.422 & 0.494 & 0 & 1 \\
H2 & 529 & 0.295 & 0.456 & 0 & 1 \\
H3 & 529 & 0.336 & 0.473 & 0 & 1 \\
H4a & 529 & 0.274 & 0.446 & 0 & 1 \\
H4b & 529 & 0.263 & 0.441 & 0 & 1 \\
H5 & 529 & 0.321 & 0.467 & 0 & 1 \\
H6 & 529 & 0.382 & 0.486 & 0 & 1 \\
H7 & 529 & 0.242 & 0.429 & 0 & 1 \\
H8 & 529 & 0.278 & 0.448 & 0 & 1 \\
Productivity & 529 & 14.392 & 2.927 & 5.15 & 23.187 \\
LnFirmge & 529 & 2.081 & 0.906 & 0 & 4.443 \\
Exporter & 529 & 1.206 & 6.673 & 0 & 90 \\
Private domestic & 529 & 76.864 & 40.683 & 0 & 100 \\
Foreign private & 529 & 14.603 & 33.943 & 0 & 100 \\
Female ownership & 529 & 1.828 & 0.378 & 1 & 2 \\
Internal funding & 529 & 89.813 & 19.678 & 0 & 100 \\
Borrowed from banks & 529 & 2.047 & 8.398 & 0 & 100 \\
Borrowed-non-banks & 529 & 1.314 & 6.73 & 0 & 70 \\
Trade credit & 529 & 4.172 & 12.877 & 0 & 100 \\
Active line of credit & 529 & 1.87 & 0.337 & 1 & 2 \\
Top manager experience & 529 & 13.822 & 10.14 & 1 & 66 \\
\hline & & & & 0 \\
\hline
\end{tabular}

Table 3. Pairwise correlations.

\begin{tabular}{|c|c|c|c|c|c|c|c|c|c|c|c|c|}
\hline Variables & (1) & (2) & (3) & (4) & (5) & (6) & (7) & (8) & (9) & (10) & (11) & $(12)$ \\
\hline (1) Productivity & 1.000 & & & & & & & & & & & \\
\hline (2) LnFirmge & 0.073 & 1.000 & & & & & & & & & & \\
\hline (3) Exporter & 0.179 & 0.102 & 1.000 & & & & & & & & & \\
\hline (4) Private domestic & -0.180 & 0.042 & -0.080 & 1.000 & & & & & & & & \\
\hline (5) Foreign private & 0.221 & -0.017 & 0.122 & -0.759 & 1.000 & & & & & & & \\
\hline (6) Female Ownership & 0.120 & -0.009 & 0.011 & -0.024 & 0.009 & 1.000 & & & & & & \\
\hline (7) Internal Funds & -0.132 & -0.068 & -0.093 & 0.097 & -0.142 & -0.005 & 1.000 & & & & & \\
\hline (8) Borrowed-banks & 0.118 & 0.084 & 0.103 & -0.063 & 0.068 & 0.000 & -0.503 & 1.000 & & & & \\
\hline (9) Borrowed-nonBank & -0.012 & -0.043 & -0.006 & 0.047 & -0.028 & 0.007 & -0.388 & 0.067 & 1.000 & & & \\
\hline (10) Trade credit & 0.148 & 0.064 & 0.038 & -0.133 & 0.191 & 0.036 & -0.720 & 0.052 & 0.057 & 1.000 & & \\
\hline (11) Line of credit & -0.013 & -0.061 & -0.031 & 0.070 & -0.053 & 0.002 & 0.219 & -0.217 & -0.141 & -0.087 & 1.000 & \\
\hline (12) Top M. Exper. & 0.100 & 0.566 & 0.085 & -0.004 & 0.034 & -0.002 & -0.018 & 0.030 & -0.064 & 0.057 & -0.032 & 1.000 \\
\hline
\end{tabular}


Table 4. Two-way measure of association between Firm size and Product innovation (H1).

\begin{tabular}{|c|c|c|c|c|c|}
\hline & \multicolumn{5}{|c|}{ Firm Size } \\
\hline & & Small $\geq 5$ & Medium $\geq 19$ & Large $\geq 19$ & Total \\
\hline \multirow{7}{*}{$\mathrm{H} 1$} & No & 234 & 60 & 12 & 306 \\
\hline & $\%$ & 76.47 & 19.61 & 3.92 & 100.00 \\
\hline & Yes & 152 & 57 & 14 & 223 \\
\hline & & & & & \\
\hline & $\%$ & 68.16 & 25.56 & 6.28 & 100.00 \\
\hline & Total & 386 & 117 & 26 & 529 \\
\hline & $\%$ & 72.97 & 22.12 & 4.91 & 100.00 \\
\hline
\end{tabular}

Pearson chi2(2) $=4.7446 ; \operatorname{Pr}=0.093 ;$ Cramér's V = 0.0947; Notes: 1) Pearson's chi-squared statistic is computed for the hypothesis that the rows and columns in a two-way table are independent. 2) Cramer's $V$ is a measure of association between two nominal variables, giving a value between 0 and 1 . It is based on Pearson's chi-squared statistic. In Table 4, we report the two-way association between firm size and new product innovation. Firms that did not introduce significantly new product in the last three 3) years are marked as no $(\mathrm{No}=0)$ whilst firms that introduce significantly new technology/methods of production in the last three years are marked as yes (Yes $=1$ ). We report that 223 of the firms introduced significantly new technology/methods. Out of this number, $68.16 \%$ are small firms, $25.56 \%$ are medium firms and $6.28 \%$ are large firms.

Table 5. Two-way measure of association between Firm size and Process innovation (H3).

\begin{tabular}{|c|c|c|c|c|c|}
\hline & \multicolumn{5}{|c|}{ Firm Size } \\
\hline & & Small $\geq 5$ & Medium $\geq 19$ & Large $\geq 19$ & Total \\
\hline \multirow{7}{*}{ H3 } & No & 268 & 71 & 12 & 351 \\
\hline & $\%$ & 76.35 & 20.23 & 3.42 & 100.00 \\
\hline & Yes & 118 & 46 & 14 & 178 \\
\hline & & & & & \\
\hline & $\%$ & 66.29 & 25.84 & 7.87 & 100.00 \\
\hline & Total & 386 & 117 & 26 & 529 \\
\hline & $\%$ & 72.97 & 22.12 & 4.91 & 100.00 \\
\hline
\end{tabular}

Pearson chi2(2) $=8.0727 ; \operatorname{Pr}=0.018 ;$ Cramér's V $=0.1235 ;$ Notes: 1 ) Pearson's chi-squared statistic is computed for the hypothesis that the rows and columns in a two-way table are independent. 2) Cramer's $\mathrm{V}$ is a measure of association between two nominal variables, giving a value between 0 and 1 . It is based on Pearson's chi-squared statistic. In Table 5, we report the two-way association between firm size and new process innovation. Firms that did not introduce significantly new technology/methods in the last three years are marked as no $(\mathrm{No}=0)$ whilst firms that introduce significantly new technology/methods of production in the last three 3 ) years are marked as yes $($ Yes $=1)$. We identify that 178 of the firms introduced significantly new technology/methods. Out of this number, $66.29 \%$ are small firms, $25.84 \%$ are medium firms and $7.87 \%$ are large firms. 
In Table 7, we report the two-way association between firm size and R\&D spending. Firms with no R\&D spending in the last three years are marked as no $(\mathrm{No}=0)$ whilst firms with R\&D spending in the last three years are marked as yes (Yes $=1)$. We identify that 128 of the firms spent on $R \& D$ in the last three years. Out of this number, $61.72 \%$ are small firms, $28.91 \%$ are medium firms and $9.38 \%$ are large firms.

Table 6. Two-way measure of association between Firm size and Active line of credit from financial institutions.

\begin{tabular}{|c|c|c|c|c|c|}
\hline & & \multicolumn{4}{|c|}{ Firm size } \\
\hline & & Small $\geq 5$ & Medium $\geq 19$ & Large $\geq 19$ & Total \\
\hline \multirow{6}{*}{$\begin{array}{l}\text { Line of credit } \\
(\mathrm{k} 8)\end{array}$} & Yes & 38 & 23 & 8 & 69 \\
\hline & $\%$ & 55.07 & 33.33 & 11.59 & 100.00 \\
\hline & No & 348 & 94 & 18 & 460 \\
\hline & $\%$ & 75.65 & 20.43 & 3.91 & 100.00 \\
\hline & Total & 386 & 117 & 26 & 529 \\
\hline & $\%$ & 72.97 & 22.12 & 4.91 & 100.00 \\
\hline
\end{tabular}

Pearson chi2 $(2)=15.1985 ; \mathrm{Pr}=0.001$; Cramér's V = 0.1695; Notes: 1 ) Pearson's chi-squared statistic is computed for the hypothesis that the rows and columns in a two-way table are independent. 2) Cramer's $\mathrm{V}$ is a measure of association between two nominal variables, giving a value between 0 and 1 . It is based on Pearson's chi-squared statistic. In Table 6, we report the two-way association between firm size and the availability of active line of credit. We identified that only 69 firms have active line of credit from financial institutions in the last three 3) years are marked as yes (Yes $=1$ ) whilst firms that did not have active line of credit from financial institutions in the last three years are marked as no (No=0). Out of the 69 firms with active line of credit from financial institutions $55.07 \%$ are small firms, $33.33 \%$ are medium firms and $11.59 \%$ are large firms.

Table 7. Two-way measure of association between Firm size and R\&D spending.

\begin{tabular}{|c|c|c|c|c|c|}
\hline & \multicolumn{5}{|c|}{ Firm size } \\
\hline & & Small $\geq 5$ & Medium $\geq 19$ & Large $\geq 19$ & Total \\
\hline \multirow{6}{*}{$\begin{array}{l}\text { R\&D spending } \\
(\mathrm{H} 7)\end{array}$} & No & 307 & 80 & 14 & 401 \\
\hline & $\%$ & 76.56 & 19.95 & 3.49 & 100.00 \\
\hline & Yes & 79 & 37 & 12 & 128 \\
\hline & $\%$ & 61.72 & 28.91 & 9.38 & 100.00 \\
\hline & Total & 386 & 117 & 26 & 529 \\
\hline & $\%$ & 72.97 & 22.12 & 4.91 & 100.00 \\
\hline
\end{tabular}

Pearson chi2(2) = 13.2815; $\mathrm{Pr}=0.001$; Cramér's V = 0.1585; Notes: 1 ) Pearson's chi-squared statistic is computed for the hypothesis that the rows and columns in a two-way table are independent. 2) Cramer's V is a measure of association between two nominal variables, giving a value between 0 and 1 . It is based on Pearson's chi-squared statistic. 


\section{Empirical Results}

The empirical results of this study are reported in this section. Table 8 captures the OLS regression of Firm Productivity and Business Environment constraints. Table 9 reports firm productivity, firm innovation and active line of credit, Table 10 shows the regression results for firm productivity, innovation and active line of credit (using firm cluster), and Table 11 also presents the regression results between firm innovation and working capital sources (logit regression).

Analysis of the business environment constraints on firm productivity is produced in Table 8 below. We identified that firm productivity is adversely affected by many other factors beyond funding and the technological progress of the firm. We find that political instability, access to land, activities of competitors of in the informal sector, theft and robbery, inadequate educated workforce and the size of the firms' locality negatively affects productivity. These findings are consistent with (Ayyagari et al., 2011) who also establish an adverse relationship between firm productivity and a constrained business environment in less developed economies. Specifically, we identified that, obstacles to access to land negatively affects firm productivity to a great deal of $68 \%$. While inadequate educated workforce negatively affects productivity, we find that capital per work positively and significantly affects productivity in DR Congo.

Table 8. Firm productivity and business environment constraints.

\begin{tabular}{|c|c|}
\hline Variables & $\stackrel{(1)}{\text { B. Constraint }}$ \\
\hline \multirow[t]{2}{*}{ Obstacle: access to land } & $-0.680^{* * *}$ \\
\hline & $(0.151)$ \\
\hline \multirow[t]{2}{*}{ Obstacle: theft \& robbery } & 0.00218 \\
\hline & $(0.0315)$ \\
\hline \multirow[t]{2}{*}{ Obstacle: practices of competitors } & $-0.480^{\star * \star}$ \\
\hline & $(0.104)$ \\
\hline \multirow[t]{2}{*}{ Obstacle: political instability } & -0.567 \\
\hline & $(0.423)$ \\
\hline \multirow[t]{2}{*}{ Obstacle: educated workforce } & $-0.345^{*}$ \\
\hline & $(0.171)$ \\
\hline \multirow[t]{2}{*}{$\mathrm{N}$ (Capital per worker) } & $0.361^{\star *}$ \\
\hline & $(0.175)$ \\
\hline \multirow[t]{2}{*}{ Size of locality } & $-3.418^{*}$ \\
\hline & $(1.764)$ \\
\hline \multirow[t]{2}{*}{ Constant } & $21.15^{\star * *}$ \\
\hline & $(3.996)$ \\
\hline Observations & 435 \\
\hline R-squared & 0.534 \\
\hline
\end{tabular}

Robust standard errors in parentheses; ${ }^{* *} p<0.01,{ }^{* *} p<0.05,{ }^{\star} p<0.1$. 
Table 9. Firm productivity, innovation and active line of credit.

\begin{tabular}{|c|c|c|c|c|c|c|c|c|c|}
\hline \multirow{2}{*}{ Variables } & $\begin{array}{l}\text { (Product } \\
\text { Inn) }\end{array}$ & $\begin{array}{l}\text { (New } \\
\text { rod) }\end{array}$ & $\begin{array}{l}\text { (Process } \\
\text { Inn) }\end{array}$ & $\begin{array}{c}(\mathrm{New} \\
\text { logistics })\end{array}$ & $\begin{array}{l}(\mathrm{New} \\
\text { Struct })\end{array}$ & \multicolumn{2}{|c|}{ (Organisation) (Marketing) } & \multirow{2}{*}{$\begin{array}{c}\begin{array}{c}\text { (R\&D } \\
\text { spending) }\end{array} \\
\text { H7 }\end{array}$} & \multirow{2}{*}{$\begin{array}{c}\text { (Employees) } \\
\text { H8 }\end{array}$} \\
\hline & $\mathrm{H} 1$ & $\mathrm{H} 2$ & $\mathrm{H} 3$ & $\mathrm{H} 4 \mathrm{a}$ & $\mathrm{H} 4 \mathrm{~b}$ & H5 & H6 & & \\
\hline \multirow[t]{2}{*}{ 0b.h1\#c.k8 } & 0.0435 & & & & & & & & \\
\hline & $(0.0620)$ & & & & & & & & \\
\hline \multirow[t]{2}{*}{ 1.h1\#c.k8 } & 0.0763 & & & & & & & & \\
\hline & $(0.0963)$ & & & & & & & & \\
\hline \multirow[t]{2}{*}{ LnFirmge } & -0.0349 & -0.0287 & -0.0362 & -0.0273 & -0.0312 & -0.0451 & -0.0386 & -0.0173 & -0.0261 \\
\hline & $(0.177)$ & $(0.177)$ & $(0.178)$ & $(0.178)$ & $(0.179)$ & $(0.178)$ & $(0.178)$ & $(0.181)$ & $(0.177)$ \\
\hline \multirow[t]{2}{*}{ Exporter } & $0.0715^{\star * *}$ & $0.0710^{\star * \star}$ & $0.0713^{\star * *}$ & $0.0710^{* * *}$ & $0.0711^{\star * \star}$ & $0.0719^{* * *}$ & $0.0717^{\star * *}$ & $0.0714^{\star * *}$ & $0.0706^{* * *}$ \\
\hline & $(0.0257)$ & $(0.0254)$ & $(0.0257)$ & $(0.0254)$ & $(0.0256)$ & $(0.0260)$ & $(0.0258)$ & $(0.0255)$ & $(0.0252)$ \\
\hline \multirow[t]{2}{*}{ Private domestic } & -0.00157 & -0.00169 & -0.00138 & -0.00164 & -0.00158 & -0.00131 & -0.00133 & -0.00173 & -0.00170 \\
\hline & $(0.00344)$ & $(0.00350)$ & $(0.00353)$ & $(0.00343)$ & $(0.00347)$ & $(0.00344)$ & $(0.00347)$ & $(0.00345)$ & $(0.00345)$ \\
\hline \multirow[t]{2}{*}{ Private foreign } & $0.0144^{\star * *}$ & $0.0143^{* * *}$ & $0.0146^{* * *}$ & $0.0145^{\star * *}$ & $0.0144^{* * *}$ & $0.0145^{\star * *}$ & $0.0147^{* * *}$ & $0.0145^{\star * *}$ & $0.0144^{* * *}$ \\
\hline & $(0.00514)$ & $(0.00519)$ & $(0.00520)$ & $(0.00511)$ & $(0.00515)$ & $(0.00513)$ & $(0.00515)$ & $(0.00510)$ & $(0.00512)$ \\
\hline \multirow[t]{2}{*}{ Female ownership } & $0.697^{\star * *}$ & $0.689^{* * *}$ & $0.698^{* * *}$ & $0.688^{* * *}$ & $0.689^{* * *}$ & $0.677^{* * *}$ & $0.682^{* * *}$ & $0.710^{* * *}$ & $0.702^{* * *}$ \\
\hline & $(0.0891)$ & $(0.0886)$ & $(0.0897)$ & $(0.0903)$ & $(0.0928)$ & $(0.0961)$ & $(0.0937)$ & $(0.0942)$ & $(0.0918)$ \\
\hline \multirow[t]{2}{*}{ Internal Funds } & 0.0154 & 0.0158 & 0.0156 & 0.0157 & 0.0156 & 0.0155 & 0.0154 & 0.0154 & 0.0160 \\
\hline & $(0.0166)$ & $(0.0165)$ & $(0.0165)$ & $(0.0165)$ & $(0.0164)$ & $(0.0166)$ & $(0.0167)$ & $(0.0164)$ & $(0.0164)$ \\
\hline \multirow[t]{2}{*}{ WC from Banks } & $0.0438^{* *}$ & $0.0441^{\star *}$ & $0.0442^{\star *}$ & $0.0440^{* *}$ & $0.0440^{* *}$ & $0.0437^{* *}$ & $0.0439^{* *}$ & $0.0443^{\star *}$ & $0.0444^{\star *}$ \\
\hline & $(0.0210)$ & $(0.0208)$ & $(0.0208)$ & $(0.0208)$ & $(0.0208)$ & $(0.0211)$ & $(0.0211)$ & $(0.0208)$ & $(0.0207)$ \\
\hline \multirow[t]{2}{*}{ WC from Non-Banks } & 0.00979 & 0.0108 & 0.00994 & 0.0108 & 0.0102 & 0.00988 & 0.00976 & 0.0101 & 0.0107 \\
\hline & $(0.0200)$ & $(0.0199)$ & $(0.0198)$ & $(0.0198)$ & $(0.0197)$ & $(0.0198)$ & $(0.0198)$ & $(0.0197)$ & $(0.0196)$ \\
\hline \multirow[t]{2}{*}{ WC. Trade Credit } & $0.0345^{*}$ & $0.0351^{\star}$ & $0.0346^{*}$ & $0.0348^{*}$ & $0.0347^{\star}$ & $0.0346^{*}$ & $0.0346^{*}$ & $0.0346^{*}$ & $0.0352^{*}$ \\
\hline & $(0.0208)$ & $(0.0207)$ & $(0.0207)$ & $(0.0206)$ & $(0.0206)$ & $(0.0208)$ & $(0.0208)$ & $(0.0206)$ & $(0.0205)$ \\
\hline \multirow[t]{2}{*}{ Top Manager Exp. } & 0.0171 & 0.0164 & 0.0174 & 0.0162 & 0.0166 & 0.0174 & 0.0174 & 0.0161 & 0.0163 \\
\hline & $(0.0161)$ & $(0.0164)$ & $(0.0161)$ & $(0.0163)$ & $(0.0165)$ & $(0.0161)$ & $(0.0162)$ & $(0.0164)$ & $(0.0165)$ \\
\hline \multirow[t]{2}{*}{ Firm Size } & 0.499 & 0.508 & 0.498 & 0.511 & 0.503 & 0.490 & 0.494 & 0.510 & 0.516 \\
\hline & $(0.316)$ & $(0.314)$ & $(0.315)$ & $(0.314)$ & $(0.316)$ & $(0.315)$ & $(0.315)$ & $(0.315)$ & $(0.313)$ \\
\hline \multirow[t]{2}{*}{ Industry } & 0.00142 & 0.00111 & 0.00159 & 0.00107 & 0.00119 & 0.00108 & 0.00125 & 0.00133 & 0.00104 \\
\hline & $(0.00773)$ & $(0.00778)$ & $(0.00774)$ & $(0.00776)$ & $(0.00771)$ & $(0.00770)$ & $(0.00770)$ & $(0.00770)$ & $(0.00771)$ \\
\hline \multirow[t]{2}{*}{ 0b.h2\#c.k8 } & & 0.0555 & & & & & & & \\
\hline & & $(0.0622)$ & & & & & & & \\
\hline \multirow[t]{2}{*}{ 1.h2\#c.k8 } & & 0.0359 & & & & & & & \\
\hline & & $(0.104)$ & & & & & & & \\
\hline
\end{tabular}




\section{Continued}

0b.h3\#c.k8

1.h3\#c.k8

1.h4a\#c.k8

0b.h4b\#c.k8

1.h4b\#c.k8

0b.h5\#c.k8

1.h5\#c.k8

1.h6\#c.k8

0b.h7\#c.k8

1.h7\#c.k8

0b.h8\#c.k8

1.h8\#c.k8

Constant

$$
\begin{array}{ll}
10.38^{\star * \star} & 10.37^{\star * *} \\
(1.762) & (1.754)
\end{array}
$$

529

529

0.152

0.152

R-squared
0.0398

(0.0585)

0.0895

(0.111)

0.0587

(0.0607)

0.0327

(0.115)

0.0489

(0.0679)

0.0638

(0.0858)

0.0230

(0.0667)

0.115

$(0.0864)$

0.0227

$(0.0710)$

0.0907

(0.0808)

0.0725

(0.0663)

$-0.0149$

(0.0914)

0.0728

(0.0675)

0.0126

(0.0925)

$10.34^{* * *}$

$10.38^{* * *}$

$10.39^{* * *}$

$10.44^{* * *}$

$10.42^{\star * *}$

$10.34^{* * *}$

$10.31^{* * *}$

(1.762)

(1.755)

(1.760)

(1.779)

(1.778)

(1.753)

(1.755)

529

529

529

529

0.152

0.152

0.152

0.153

0.153

0.153

0.152

Robust standard errors in parentheses; ${ }^{* *} p<0.01,{ }^{* *} p<0.05,{ }^{*} p<0.1$; Note: $(0 \mathrm{~b} . \mathrm{h} 2 \#$ c.k8, 1.h2\#c.k8, 0b.h3\#c.k8, 1.h3\#c.k8, 1.h4a\#c.k8, 1.h4b\#c.k8, 0b.h5\#c.k8, 1.h5\#c.k8, 0b.h6\#c.k8, 1.h6\#c.k8, 0b.h7\#c.k8, 1.h7\#c.k8, 0b.h8\#c.k8, and 1.h8\#c.k8) are the interactive terms between firm innovation and active line of credit. Analysis to establish a transmission mechanism from firm innovation activities on productivity through external funding sources (firms with active line of credit) is reported in table 9 above. We establish a positive and significant effect of exporter firms, foreign private firms, firms with female ownership, working capital borrowed from banks and trade credit on productivity. We also identify that the interactive term between firm innovation activities and active line of credit is positive. Internal source of working capital is statistically insignificant but positive. External funding sources of working capital (borrowing from banks and trade credit) maintains a crucial role. 
Table 10. Firm productivity, innovation and active line of credit (using firm clusters).

\begin{tabular}{|c|c|c|c|c|c|c|c|c|c|}
\hline \multirow{2}{*}{ Variables } & \multirow{2}{*}{$\begin{array}{c}\begin{array}{c}\text { (Product } \\
\text { Inn) }\end{array} \\
\text { H1 }\end{array}$} & \multirow{2}{*}{$\begin{array}{c}\text { (New } \\
\text { Prod) }\end{array}$} & \multirow{2}{*}{$\begin{array}{c}\begin{array}{c}\text { (Process } \\
\text { Inn) }\end{array} \\
\text { H3 }\end{array}$} & \multirow{2}{*}{$\begin{array}{c}\begin{array}{c}(\mathrm{New} \\
\text { logistics })\end{array} \\
\mathrm{H} 4 \mathrm{a}\end{array}$} & \multirow{2}{*}{$\begin{array}{c}\begin{array}{c}(\mathrm{New} \\
\text { Struct })\end{array} \\
\mathrm{H} 4 \mathrm{~b}\end{array}$} & \multicolumn{2}{|c|}{ (Organisation) (Marketing) } & \multirow{2}{*}{$\begin{array}{c}\begin{array}{c}(\mathrm{R} \& \mathrm{D} \\
\text { spending }\end{array} \\
\mathrm{H} 7\end{array}$} & \multirow{2}{*}{$\frac{\text { (Employees) }}{\mathrm{H} 8}$} \\
\hline & & & & & & H5 & H6 & & \\
\hline \multirow[t]{2}{*}{ 0b.h1\#c.k8 } & -0.0384 & & & & & & & & \\
\hline & $(0.133)$ & & & & & & & & \\
\hline \multirow[t]{2}{*}{ 1.h1\#c.k8 } & 0.262 & & & & & & & & \\
\hline & $(0.209)$ & & & & & & & & \\
\hline \multirow[t]{2}{*}{ LnFirmge } & -0.154 & -0.142 & -0.147 & -0.142 & -0.144 & -0.130 & -0.0850 & -0.133 & -0.126 \\
\hline & $(0.241)$ & $(0.240)$ & $(0.241)$ & $(0.238)$ & $(0.238)$ & $(0.237)$ & $(0.241)$ & $(0.241)$ & $(0.240)$ \\
\hline \multirow[t]{2}{*}{ Capacity Utilisation } & 0.00415 & 0.00498 & 0.00521 & 0.00487 & 0.00169 & 0.00443 & 0.00241 & 0.00363 & 0.00464 \\
\hline & $(0.00761)$ & $(0.00780)$ & $(0.00783)$ & $(0.00766)$ & $(0.00723)$ & $(0.00742)$ & $(0.00755)$ & $(0.00765)$ & $(0.00773)$ \\
\hline \multirow[t]{2}{*}{ Educated labour force } & -0.0331 & -0.0329 & -0.0299 & -0.0350 & -0.0410 & -0.0329 & -0.0370 & -0.0303 & -0.0291 \\
\hline & $(0.0637)$ & $(0.0649)$ & $(0.0645)$ & $(0.0635)$ & $(0.0630)$ & $(0.0637)$ & $(0.0636)$ & $(0.0644)$ & $(0.0648)$ \\
\hline \multirow[t]{2}{*}{$\operatorname{Ln}$ (Capital per worker) } & $0.342^{* * *}$ & $0.338^{\star * *}$ & $0.332^{* * *}$ & $0.325^{\star * *}$ & $0.341^{* * *}$ & $0.326^{* * *}$ & $0.344^{* * *}$ & $0.344^{* * *}$ & $0.337^{* * *}$ \\
\hline & $(0.0700)$ & $(0.0712)$ & $(0.0706)$ & $(0.0714)$ & $(0.0691)$ & $(0.0705)$ & $(0.0708)$ & $(0.0712)$ & $(0.0716)$ \\
\hline \multirow[t]{2}{*}{ Exporter } & $0.153^{* * *}$ & $0.150^{\star * *}$ & $0.149^{* * *}$ & $0.152^{* * *}$ & $0.147^{\star * *}$ & $0.157^{* * *}$ & $0.158^{* * *}$ & $0.150^{* * *}$ & $0.149^{* * *}$ \\
\hline & $(0.0301)$ & $(0.0299)$ & $(0.0297)$ & $(0.0303)$ & $(0.0314)$ & $(0.0303)$ & $(0.0301)$ & $(0.0292)$ & $(0.0293)$ \\
\hline \multirow[t]{2}{*}{ Private domestic } & -0.00311 & -0.00300 & -0.00310 & -0.00350 & -0.00409 & -0.00454 & -0.00311 & -0.00339 & -0.00331 \\
\hline & $(0.00486)$ & $(0.00489)$ & $(0.00491)$ & $(0.00483)$ & $(0.00511)$ & $(0.00472)$ & $(0.00474)$ & $(0.00482)$ & $(0.00473)$ \\
\hline \multirow[t]{2}{*}{ Private foreign } & $0.0153^{* *}$ & $0.0160^{\star *}$ & $0.0152^{\star *}$ & $0.0145^{\star *}$ & $0.0131^{*}$ & $0.0135^{\star *}$ & $0.0150^{\star *}$ & $0.0148^{\star \star}$ & $0.0151^{\star *}$ \\
\hline & $(0.00697)$ & $(0.00698)$ & $(0.00704)$ & $(0.00710)$ & $(0.00728)$ & $(0.00681)$ & $(0.00672)$ & $(0.00692)$ & $(0.00688)$ \\
\hline \multirow[t]{2}{*}{ Female ownership } & 0.570 & 0.569 & 0.579 & 0.586 & 0.537 & 0.534 & 0.568 & 0.550 & 0.573 \\
\hline & $(0.469)$ & $(0.472)$ & $(0.462)$ & $(0.449)$ & $(0.447)$ & $(0.455)$ & $(0.467)$ & $(0.467)$ & $(0.473)$ \\
\hline \multirow[t]{2}{*}{ Internal Funds } & -0.0198 & -0.0179 & -0.0155 & -0.0161 & -0.0151 & -0.0203 & -0.0174 & -0.0168 & -0.0176 \\
\hline & $(0.0223)$ & $(0.0216)$ & $(0.0209)$ & $(0.0192)$ & $(0.0183)$ & $(0.0215)$ & $(0.0193)$ & $(0.0212)$ & $(0.0216)$ \\
\hline \multirow[t]{2}{*}{ WC from Banks } & -0.000384 & 0.00164 & 0.00361 & 0.00480 & 0.00805 & 0.00205 & $-5.74 \mathrm{e}-05$ & 0.00269 & 0.00169 \\
\hline & $(0.0333)$ & $(0.0327)$ & $(0.0320)$ & $(0.0308)$ & $(0.0303)$ & $(0.0321)$ & $(0.0307)$ & $(0.0318)$ & $(0.0319)$ \\
\hline \multirow[t]{2}{*}{ WC from Non-Banks } & -0.0326 & -0.0282 & -0.0248 & -0.0296 & -0.0304 & -0.0313 & -0.0303 & -0.0258 & -0.0261 \\
\hline & $(0.0258)$ & $(0.0259)$ & $(0.0249)$ & $(0.0244)$ & $(0.0237)$ & $(0.0257)$ & $(0.0235)$ & $(0.0249)$ & $(0.0257)$ \\
\hline \multirow[t]{2}{*}{ WC. Trade Credit } & -0.0182 & -0.0153 & -0.0130 & -0.0131 & -0.0119 & -0.0169 & -0.0132 & -0.0133 & -0.0142 \\
\hline & $(0.0246)$ & $(0.0239)$ & $(0.0237)$ & $(0.0225)$ & $(0.0220)$ & $(0.0238)$ & $(0.0222)$ & $(0.0234)$ & $(0.0238)$ \\
\hline \multirow[t]{2}{*}{ Top Manager Exp. } & 0.0119 & 0.00959 & 0.0122 & 0.00942 & 0.00973 & 0.00881 & 0.00911 & 0.00855 & 0.00867 \\
\hline & $(0.0198)$ & $(0.0203)$ & $(0.0202)$ & $(0.0203)$ & $(0.0204)$ & $(0.0200)$ & $(0.0202)$ & $(0.0203)$ & $(0.0206)$ \\
\hline \multirow[t]{2}{*}{ Firm Size } & 0.596 & 0.607 & 0.586 & 0.465 & 0.437 & 0.511 & 0.462 & 0.605 & 0.616 \\
\hline & $(0.443)$ & $(0.440)$ & $(0.444)$ & $(0.449)$ & $(0.444)$ & $(0.446)$ & $(0.434)$ & $(0.452)$ & $(0.452)$ \\
\hline Industry & $-0.0398^{*}$ & -0.0388 & -0.0390 & -0.0365 & -0.0337 & -0.0355 & $-0.0403^{*}$ & -0.0374 & $-0.0396^{*}$ \\
\hline & $(0.0238)$ & $(0.0240)$ & $(0.0239)$ & $(0.0235)$ & $(0.0234)$ & $(0.0237)$ & $(0.0235)$ & $(0.0241)$ & $(0.0238)$ \\
\hline 0b.h2\#c.k8 & & -0.0212 & & & & & & & \\
\hline & & $(0.134)$ & & & & & & & \\
\hline
\end{tabular}




\section{Continued}

1.h2\#c.k8

0b.h3\#c.k8

1.h3\#c.k8

1.h4a\#c.k8

0b.h4b\#c.k8

1.h4b\#c.k8

0b.h5\#c.k8

1.h5\#c.k8

0b.h6\#c.k8

1.h6\#c.k8

ob.h7\#c.k8

1.h7\#c.k8

0b.h8\#c.k8

1.h8\#c.k8 0b.h4a\#c.k8

0.148

(0.231)

$-0.0290$

(0.134)

0.176

$(0.217)$

$-0.0454$

(0.133)

$0.450^{\star}$

(0.248)

$-0.0388$

(0.129)

$0.621^{\star *}$

$(0.300)$

$-0.0904$

(0.132)

$0.339^{* *}$

(0.153)

$-0.144$

(0.150)

0.246

(0.153)

$-0.0716$

(0.154)

0.132

(0.149)

$-0.0411$

(0.154)

0.0559

(0.154)

Constant

$$
\begin{array}{ll}
11.08^{* * *} & 10.96^{* * *} \\
(2.578) & (2.565)
\end{array}
$$

$10.73^{\star * *}$

$11.03^{* * *}$

$11.15^{\text {***}}$

$11.64^{\star * *}$

$11.27^{* * *}$

$11.00^{* * *}$

$11.02^{* * *}$

(2.480)

(2.335)

(2.266)

(2.579)

(2.350)

(2.535)

(2.575)

Observations

231

231

231

231

231

231

231

231

231

0.294

0.288

0.288

0.272

0.268

Robust standard errors in parentheses; ${ }^{* *} p<0.01,{ }^{* *} p<0.05,{ }^{*} p<0.1$; Note: (0b.h2\#c.k8, 1.h2\#c.k8, 0b.h3\#c.k8, 1.h3\#c.k8, 1.h4a\#c.k8, 1.h4b\#c.k8, 0b.h5\#c.k8, 1.h5\#c.k8, 0b.h6\#c.k8, 1.h6\#c.k8, 0b.h7\#c.k8, 1.h7\#c.k8, 0b.h8\#c.k8, and 1.h8\#c.k8) are the interactive terms between firm innovation and active line of credit. Further analysis to establish a transmission mechanism from firm innovation activities on productivity through external funding sources (firms with active line of credit) is performed through clustering. We established positive and significant effect of exporter firms, foreign private firms, capital per worker on productivity. We also identify that the interactive term between firm innovation activities and active line of credit is positive statistically significant. We establish the transmission mechanism of firm innovation on productivity through lines of credit. 
Table 11. Firm innovation and working capital sources (Logit regression).

\begin{tabular}{|c|c|c|c|c|c|c|c|c|c|}
\hline \multirow{2}{*}{ Variables } & \multirow{2}{*}{$\begin{array}{c}\begin{array}{c}\text { (Product } \\
\text { Inn) }\end{array} \\
\text { H1 }\end{array}$} & \multirow{2}{*}{$\begin{array}{c}\left(\begin{array}{c}\text { New } \\
\text { Prod })\end{array}\right. \\
\mathrm{H} 2\end{array}$} & \multirow{2}{*}{$\begin{array}{c}\text { (Process } \\
\text { Inn) }\end{array}$} & \multirow{2}{*}{$\begin{array}{c}\begin{array}{c}(\mathrm{New} \\
\text { logistics })\end{array} \\
\mathrm{H} 4 \mathrm{a}\end{array}$} & \multirow{2}{*}{$\begin{array}{c}\begin{array}{c}(\mathrm{New} \\
\text { Struct })\end{array} \\
\mathrm{H} 4 \mathrm{~b}\end{array}$} & \multicolumn{2}{|c|}{ (Organisation) (Marketing) } & \multirow{2}{*}{$\begin{array}{c}\begin{array}{c}(\mathrm{R} \& \mathrm{D} \\
\text { spending })\end{array} \\
\mathrm{H} 7\end{array}$} & \multirow{2}{*}{$\begin{array}{c}\text { (Employees) } \\
\mathrm{H} 8\end{array}$} \\
\hline & & & & & & H5 & H6 & & \\
\hline \multirow[t]{2}{*}{ Productivity } & 0.000621 & 0.0145 & -0.0192 & -0.00373 & 0.0293 & 0.0231 & 0.0566 & -0.00223 & -0.0358 \\
\hline & $(0.0345)$ & $(0.0408)$ & $(0.0378)$ & $(0.0413)$ & $(0.0426)$ & $(0.0384)$ & $(0.0363)$ & $(0.0425)$ & $(0.0397)$ \\
\hline \multirow[t]{2}{*}{ LnFirmge } & 0.156 & 0.0985 & 0.130 & 0.150 & 0.174 & $0.318^{\star *}$ & 0.183 & $0.490^{\star * *}$ & 0.164 \\
\hline & $(0.125)$ & $(0.132)$ & $(0.127)$ & $(0.130)$ & $(0.136)$ & $(0.138)$ & $(0.128)$ & $(0.156)$ & $(0.142)$ \\
\hline \multirow[t]{2}{*}{ Exporter } & -0.00362 & 0.0120 & 0.0124 & 0.0205 & $0.0254^{\star}$ & 0.0253 & 0.00621 & $0.0235^{\star}$ & $0.0243^{*}$ \\
\hline & $(0.0139)$ & $(0.0139)$ & $(0.0134)$ & $(0.0135)$ & $(0.0153)$ & $(0.0161)$ & $(0.0133)$ & $(0.0141)$ & $(0.0133)$ \\
\hline \multirow[t]{2}{*}{ Private Domestic } & $-0.00821^{\star *}$ & $-0.0137^{\star * *}$ & $-0.00935^{\star * *}$ & 0.000695 & $-0.00589^{\star}$ & $-0.00962^{\star * *}$ & $-0.00980^{\star * *}$ & $-0.00654^{\star}$ & -0.00490 \\
\hline & $(0.00331)$ & $(0.00335)$ & $(0.00332)$ & $(0.00377)$ & $(0.00352)$ & $(0.00331)$ & $(0.00337)$ & $(0.00342)$ & $(0.00349)$ \\
\hline \multirow[t]{2}{*}{ Foreign private } & $-0.00723^{*}$ & $-0.0173^{* * *}$ & $-0.00744^{*}$ & 0.00422 & -0.00309 & -0.00575 & $-0.00775^{\star}$ & -0.00461 & -0.00439 \\
\hline & $(0.00404)$ & $(0.00442)$ & $(0.00412)$ & $(0.00466)$ & $(0.00453)$ & $(0.00425)$ & $(0.00425)$ & $(0.00451)$ & $(0.00443)$ \\
\hline \multirow[t]{2}{*}{ Female ownership } & -0.102 & -0.165 & -0.0370 & -0.135 & $-0.173^{\star}$ & $-0.205^{* *}$ & $-0.291^{* *}$ & $-0.316^{* * *}$ & $-0.183^{*}$ \\
\hline & $(0.105)$ & $(0.112)$ & $(0.123)$ & $(0.123)$ & $(0.105)$ & $(0.102)$ & $(0.132)$ & $(0.119)$ & $(0.0989)$ \\
\hline \multirow[t]{2}{*}{ Internal Funds } & 0.00963 & 0.0137 & -0.00200 & 0.000210 & 0.0123 & 0.0102 & 0.000927 & 0.0205 & $0.0441^{\star *}$ \\
\hline & $(0.0118)$ & $(0.0143)$ & $(0.0119)$ & $(0.0129)$ & $(0.0147)$ & $(0.0135)$ & $(0.0114)$ & $(0.0168)$ & $(0.0208)$ \\
\hline \multirow[t]{2}{*}{ WC from Banks } & $0.0404^{\star *}$ & 0.0290 & 0.0180 & 0.0183 & $0.0336^{\star}$ & $0.0446^{\star \star}$ & 0.00774 & 0.0235 & $0.0630^{\star * *}$ \\
\hline & $(0.0198)$ & $(0.0186)$ & $(0.0185)$ & $(0.0183)$ & $(0.0181)$ & $(0.0189)$ & $(0.0156)$ & $(0.0227)$ & $(0.0239)$ \\
\hline \multirow[t]{2}{*}{ WC from Non-Banks } & $0.0424^{\star *}$ & $0.0376^{\star *}$ & 0.0218 & $0.0315^{*}$ & 0.0312 & 0.0199 & 0.0121 & 0.0135 & 0.0309 \\
\hline & $(0.0192)$ & $(0.0186)$ & $(0.0171)$ & $(0.0180)$ & $(0.0195)$ & $(0.0190)$ & $(0.0176)$ & $(0.0237)$ & $(0.0247)$ \\
\hline \multirow[t]{2}{*}{ WC. Trade Credit } & 0.0130 & 0.0211 & 0.00256 & -0.00483 & 0.0156 & 0.0111 & -0.00597 & 0.0305 & $0.0453^{*}$ \\
\hline & $(0.0145)$ & $(0.0167)$ & $(0.0145)$ & $(0.0152)$ & $(0.0172)$ & $(0.0166)$ & $(0.0148)$ & $(0.0198)$ & $(0.0232)$ \\
\hline \multirow[t]{2}{*}{ Line of credit } & $0.109^{*}$ & $0.0989^{*}$ & 0.0775 & 0.0533 & 0.0546 & 0.0452 & -0.00181 & 0.0479 & -0.0207 \\
\hline & $(0.0555)$ & $(0.0568)$ & $(0.0593)$ & $(0.0568)$ & $(0.0534)$ & $(0.0535)$ & $(0.0448)$ & $(0.0557)$ & $(0.0459)$ \\
\hline \multirow[t]{2}{*}{ Top Manager Exp. } & -0.00609 & 0.00488 & -0.0156 & -0.000163 & -0.0115 & -0.0141 & $-0.0312^{\star *}$ & $-0.0362^{* *}$ & -0.0127 \\
\hline & $(0.0111)$ & $(0.0111)$ & $(0.0120)$ & $(0.0119)$ & $(0.0124)$ & $(0.0123)$ & $(0.0134)$ & $(0.0145)$ & $(0.0131)$ \\
\hline \multirow{2}{*}{ Firm size } & $0.323^{*}$ & $0.372^{* *}$ & $0.424^{* *}$ & $0.399^{* *}$ & $0.436^{* *}$ & $0.508^{* * *}$ & $0.684^{* * *}$ & $0.434^{* *}$ & $0.489^{* * *}$ \\
\hline & $(0.175)$ & $(0.184)$ & $(0.175)$ & $(0.184)$ & $(0.196)$ & $(0.191)$ & $(0.190)$ & $(0.196)$ & $(0.183)$ \\
\hline \multirow[t]{2}{*}{ Industry } & -0.00314 & -0.00502 & -0.00665 & -0.000960 & $0.0166^{\star \star}$ & $0.0117^{\star}$ & 0.00484 & -0.00240 & -0.00644 \\
\hline & $(0.00584)$ & $(0.00627)$ & $(0.00601)$ & $(0.00628)$ & $(0.00677)$ & $(0.00641)$ & $(0.00600)$ & $(0.00698)$ & $(0.00645)$ \\
\hline \multirow[t]{2}{*}{ Constant } & -1.171 & -1.686 & 0.0844 & -1.809 & $-3.542^{\star \star}$ & $-2.719^{\star}$ & -1.078 & $-3.182^{\star}$ & $-4.605^{\star \star}$ \\
\hline & $(1.319)$ & $(1.505)$ & $(1.317)$ & (1.403) & $(1.565)$ & $(1.472)$ & (1.287) & $(1.812)$ & (2.194) \\
\hline Observations & 529 & 529 & 529 & 529 & 529 & 529 & 529 & 529 & 529 \\
\hline McFadden's R': & 0.042 & 0.055 & 0.042 & 0.039 & 0.052 & 0.072 & 0.058 & 0.060 & 0.050 \\
\hline Count $\mathrm{R}^{2}$ : & 0.624 & 0.730 & 0.665 & 0.726 & 0.735 & 0.690 & 0.658 & 0.758 & 0.733 \\
\hline$P$ Prob $>$ chi 2 & 0.3292 & 0.3350 & 0.3003 & 0.3705 & 0.4144 & 0.3311 & 0.3046 & 0.3408 & 0.1743 \\
\hline Pseudo $\mathrm{R}^{2}$ & 0.0416 & 0.0552 & 0.0423 & 0.0390 & 0.0522 & 0.0724 & 0.0580 & 0.0596 & 0.0496 \\
\hline
\end{tabular}

Robust standard errors in parentheses; ${ }^{* *} p<0.01,{ }^{* *} p<0.05,{ }^{*} p<0.1$. 
In Table 11, we present the analysis on the relationship between firm innovation activities and working capital sources with a set of control variables including firm productivity, firm age, form ownership, firm size and the availability of an active line of credit using logit regression. We established positive and significant effect of external funding sources (funds borrowed from banks and non-banking institutions and trade credit) on firm innovation activities among firms in DR Congo. For instance a unit increase in working capital from non-banks will cause a 0.0424 and 0.0376 increase in product and process innovation among manufacturing firms in DR Congo. These finding corroborates the findings of (Fernandez, 2017) who also establish the crucial role of external funding sources for firm innovation among manufacturing firms LAC. (Ayyagari \& Maksimovic, 2007) and (Ayyagari et al., 2011) also demonstrated the significance of developed financial systems and business environment on firm productivity and innovation.

Table 12 below is the responding odds ratios of the logit regressions reported in Table 10.

Analysis of the treatment (firms with R\&D spending in the last 3 years) and control groups (firms without $R \& D$ spending in the last 3 years) through the technique of propensity score matching is reported in Table 13 below.

Our earlier findings are strengthened by the results from the propensity score matching model. We show that the Average Treatment Effect (ATE) of R\&D spending is positive and statistically significant at $5 \%$. R\&D spending impacts labour productivity nearly $53 \%$ higher on firms that spent on research and development (R\&D) than their counterparts. Similarly, the Average Treatment Effect on the Treated (ATET) is positive and statistically significant at 5\%. We report an overwhelming $112 \%$ positive effect of $\mathrm{R} \& \mathrm{D}$ spending on firm productivity of the treatment group.

Table 12. Firm innovation and working capital sources (odds ratio).

\begin{tabular}{|c|c|c|c|c|c|c|c|c|c|}
\hline \multirow{2}{*}{ Variables } & $\begin{array}{l}\text { (Product } \\
\text { Inn) }\end{array}$ & $\begin{array}{l}\text { (New } \\
\text { Prod) }\end{array}$ & $\begin{array}{l}\text { (Process } \\
\text { Inn) }\end{array}$ & $\begin{array}{c}(\mathrm{New} \\
\text { logistics) }\end{array}$ & $\begin{array}{l}\text { (New } \\
\text { Struct) }\end{array}$ & \multicolumn{2}{|c|}{ (Organisation) (Marketing) } & \multirow{2}{*}{$\begin{array}{c}\begin{array}{c}(\mathrm{R} \& \mathrm{D} \\
\text { spending) }\end{array} \\
\mathrm{H} 7\end{array}$} & \multirow{2}{*}{$\begin{array}{c}\text { (Employees) } \\
\mathrm{H} 8\end{array}$} \\
\hline & $\mathrm{H} 1$ & $\mathrm{H} 2$ & $\mathrm{H} 3$ & $\mathrm{H} 4 \mathrm{a}$ & $\mathrm{H} 4 \mathrm{~b}$ & H5 & H6 & & \\
\hline \multicolumn{10}{|l|}{ h1 } \\
\hline \multirow[t]{2}{*}{ Productivity } & 1.001 & 1.015 & 0.981 & 0.996 & 1.030 & 1.023 & 1.058 & 0.998 & 0.965 \\
\hline & $(0.0336)$ & $(0.0372)$ & $(0.0342)$ & $(0.0364)$ & $(0.0386)$ & $(0.0366)$ & $(0.0367)$ & $(0.0383)$ & $(0.0353)$ \\
\hline \multirow[t]{2}{*}{ LnFirmge } & 1.169 & 1.103 & 1.138 & 1.162 & 1.190 & $1.374^{* *}$ & 1.201 & $1.633^{* * *}$ & 1.178 \\
\hline & $(0.148)$ & $(0.152)$ & $(0.150)$ & $(0.160)$ & $(0.168)$ & $(0.189)$ & $(0.156)$ & $(0.251)$ & $(0.164)$ \\
\hline \multirow[t]{2}{*}{ Exporter } & 0.996 & 1.012 & 1.013 & 1.021 & 1.026 & 1.026 & 1.006 & 1.024 & 1.025 \\
\hline & $(0.0143)$ & $(0.0147)$ & $(0.0148)$ & $(0.0159)$ & $(0.0169)$ & $(0.0178)$ & $(0.0155)$ & $(0.0173)$ & $(0.0158)$ \\
\hline \multirow[t]{2}{*}{ Private Domestic } & $0.992^{\star \star}$ & $0.986^{* * *}$ & $0.991^{\star * \star}$ & 1.001 & $0.994^{\star}$ & $0.990^{\star * *}$ & $0.990^{\star * *}$ & $0.993^{*}$ & 0.995 \\
\hline & $(0.00327)$ & $(0.00329)$ & $(0.00325)$ & $(0.00381)$ & $(0.00347)$ & $(0.00333)$ & $(0.00330)$ & $(0.00356)$ & $(0.00346)$ \\
\hline
\end{tabular}




\section{Continued}

\begin{tabular}{|c|c|c|c|c|c|c|c|c|c|}
\hline \multirow[t]{2}{*}{ Foreign private } & $0.993^{*}$ & $0.983^{* * *}$ & $0.993^{*}$ & 1.004 & 0.997 & 0.994 & $0.992^{*}$ & 0.995 & 0.996 \\
\hline & $(0.00409)$ & $(0.00437)$ & $(0.00411)$ & $(0.00459)$ & $(0.00435)$ & $(0.00419)$ & $(0.00414)$ & $(0.00454)$ & $(0.00440)$ \\
\hline \multirow[t]{2}{*}{ Female ownership } & 0.903 & 0.848 & 0.964 & 0.874 & 0.841 & 0.815 & 0.747 & $0.729^{*}$ & 0.833 \\
\hline & $(0.111)$ & $(0.107)$ & $(0.121)$ & $(0.110)$ & $(0.109)$ & $(0.117)$ & $(0.135)$ & $(0.125)$ & $(0.119)$ \\
\hline \multirow[t]{2}{*}{ Internal Funds } & 1.010 & 1.014 & 0.998 & 1.000 & 1.012 & 1.010 & 1.001 & 1.021 & $1.045^{* *}$ \\
\hline & $(0.0121)$ & $(0.0143)$ & $(0.0119)$ & $(0.0128)$ & $(0.0146)$ & $(0.0134)$ & $(0.0119)$ & $(0.0161)$ & $(0.0193)$ \\
\hline \multirow[t]{2}{*}{ WC from Banks } & $1.041^{* *}$ & 1.029 & 1.018 & 1.018 & $1.034^{*}$ & $1.046^{* *}$ & 1.008 & 1.024 & $1.065^{* * *}$ \\
\hline & $(0.0190)$ & $(0.0189)$ & $(0.0171)$ & $(0.0176)$ & $(0.0194)$ & $(0.0198)$ & $(0.0165)$ & $(0.0210)$ & $(0.0239)$ \\
\hline \multirow[t]{2}{*}{ WC from Non-Banks } & $1.043^{* *}$ & $1.038^{\star *}$ & 1.022 & $1.032^{*}$ & 1.032 & 1.020 & 1.012 & 1.014 & 1.031 \\
\hline & $(0.0194)$ & $(0.0195)$ & $(0.0177)$ & $(0.0186)$ & $(0.0197)$ & $(0.0189)$ & $(0.0176)$ & $(0.0231)$ & $(0.0255)$ \\
\hline \multirow[t]{2}{*}{ WC. Trade Credit } & 1.013 & 1.021 & 1.003 & 0.995 & 1.016 & 1.011 & 0.994 & $1.031^{*}$ & $1.046^{* *}$ \\
\hline & $(0.0147)$ & $(0.0169)$ & $(0.0145)$ & $(0.0154)$ & $(0.0171)$ & $(0.0160)$ & $(0.0146)$ & $(0.0189)$ & $(0.0216)$ \\
\hline \multirow[t]{2}{*}{ Line of credit } & $1.115^{* *}$ & $1.104^{*}$ & 1.081 & 1.055 & 1.056 & 1.046 & 0.998 & 1.049 & 0.980 \\
\hline & $(0.0569)$ & $(0.0652)$ & $(0.0560)$ & $(0.0541)$ & $(0.0558)$ & $(0.0519)$ & $(0.0439)$ & $(0.0581)$ & $(0.0445)$ \\
\hline \multirow[t]{2}{*}{ Top Manager Exp. } & 0.994 & 1.005 & 0.984 & 1.000 & 0.989 & 0.986 & $0.969^{* * *}$ & $0.964^{* * *}$ & 0.987 \\
\hline & $(0.0109)$ & $(0.0117)$ & $(0.0115)$ & $(0.0118)$ & $(0.0123)$ & $(0.0117)$ & $(0.0116)$ & $(0.0131)$ & $(0.0118)$ \\
\hline \multirow[t]{2}{*}{ Firm size } & $1.381^{*}$ & $1.451^{\star *}$ & $1.529^{* *}$ & $1.490^{\star *}$ & $1.547^{\star *}$ & $1.662^{* * *}$ & $1.983^{* * *}$ & $1.543^{* *}$ & $1.631^{* * *}$ \\
\hline & $(0.242)$ & $(0.270)$ & $(0.273)$ & $(0.273)$ & $(0.291)$ & $(0.303)$ & $(0.360)$ & $(0.295)$ & $(0.301)$ \\
\hline \multirow[t]{2}{*}{ industry } & 0.997 & 0.995 & 0.993 & 0.999 & $1.017^{* *}$ & $1.012^{*}$ & 1.005 & 0.998 & 0.994 \\
\hline & $(0.00583)$ & $(0.00634)$ & $(0.00606)$ & $(0.00646)$ & $(0.00688)$ & $(0.00650)$ & $(0.00607)$ & $(0.00676)$ & $(0.00638)$ \\
\hline
\end{tabular}

h2

h3

$\mathrm{h} 4 \mathrm{a}$

$\mathrm{h} 4 \mathrm{~b}$

h5

h6

h7

h8

$\begin{array}{cccccccccc}\text { Constant } & 0.310 & 0.185 & 1.088 & 0.164 & 0.0289^{* *} & 0.0660^{*} & 0.340 & 0.0415^{*} & 0.0100^{* *} \\ & (0.417) & (0.287) & (1.463) & (0.235) & (0.0458) & (0.0973) & (0.458) & (0.0720) & (0.0196)\end{array}$

Observations

529

529

$529 \quad 529$

529

529

529

529

Robust standard errors in parentheses; ${ }^{* *} p<0.01,{ }^{* *} p<0.05,{ }^{*} p<0.1$. 
Table 13. Propensity Score Matching (PSM).

\begin{tabular}{cccc}
\hline Variables & $(1)$ & $(2)$ & $(3)$ \\
& ATE & ATET & ATU \\
\hline 1vs0.h7 & $0.527^{* *}$ & $1.120^{* *}$ & \\
& $(0.239)$ & $(0.440)$ & \\
1vs0.noh7 & & $9.13 \mathrm{e}-06$ \\
& & $(0.471)$ \\
Observations & 193 & 193 \\
\hline Standard errors in parentheses; ${ }^{* * *} p<0.01,{ }^{* *} p<0.05,{ }^{*} p<0.1$. &
\end{tabular}

\section{Conclusion and Recommendations}

This study employed firm level data from the World Bank's Enterprise Survey Indicator Database, https://www.enterprisesurveys.org conducted in 2013 on manufacturing firms in DR Congo. We applied log of firm-level output per worker as the key dependent variable. Firm-level innovation was broadly defined to include the introduction of significantly new products (H1), new or significantly improved methods of manufacturing products (New Technology-H3), new or significantly improved logistical or business support processes (H3), new or significantly improved organizational structures or management practices (H4a), introduced new or significantly improved marketing methods (H4b), did this establishment spend on formal research and development activities, either in-house or contracted with other companies (H5), did this establishment give employees some time to innovate or try out a new approach or new idea about the products or services (H6), business process, firm management, or marketing (H7).

We show evidence that, firm innovation significantly and positively affects firm productivity. We also show that the mediating role of well-developed financial or banking system via the availability of an active line of credit on productivity. Such that in a well-developed financial market, the impact of firm innovation is significant through the facilitation and financing of innovation activities, and innovative firms to boost productivity and lower production cost. These findings are very important for countries in Africa (and other less-developed countries) who spend less on R\&D but can adopt or imitate existing innovative ideas from technology rich countries for accelerated economic growth and increased productivity.

In our further analysis, we employed the technique of propensity score matching (PSM) to unravel the effect of R\&D spending on firm productivity. The treatment group are firms that spend on R\&D in the last three (3) years. We show that the Average Treatment Effect (ATE) of R\&D spending is positive and statistically significant at $5 \%$. R\&D spending impacts labour productivity nearly $53 \%$ higher on firms that spent on research and development (R\&D) than their counterparts. Similarly, the Average Treatment Effect on the Treated (ATET) is 
positive and statistically significant at $5 \%$. We report an overwhelming $112 \%$ positive effect of R\&D spending on firm productivity of the treatment group. The significance of these findings go beyond DR Congo to all other less developed for countries, especially those in Africa who spend woefully on R\&D but can adopt or imitate existing innovative ideas from technology-rich countries for accelerated economic growth and increased productivity.

These findings are strengthened by earlier arguments of (Hall \& Lerner, 2010; Hall, 1992; Aghion et al., 2005; Ayyagari et al., 2011; Solow, 1957) that technological advancement and skill rather than just capital accumulation that accounts for the difference in output around the world. (Solow, 1957) further demonstrated that nearly $80 \%$ of the growth in labour productivity across the US from 1909 to 1949 was accounted for by more productive use of capital and acceleration in the skills of labour through technological advancement. Hence the understanding of the relationship between firm productivity, financing constraints, and firm innovation which is the core of this study is crucial in understanding the mechanisms through which economic growth can be stimulated in DR Congo.

\section{Suggestion for Further Study}

This study is limited in terms of scope, by only examining manufacturing firms in DR Congo. It is therefore suggested for future studies to widen the scope beyond manufacturing firms and to other African countries with similar economic background.

\section{Conflicts of Interest}

The authors declare no conflicts of interest regarding the publication of this paper.

\section{References}

Adu-Danso, E., \& Abbey, E. (2020). Does Foreign Ownership Enhance Technological Innovation amongst Manufacturing Firms in Sub-Saharan Africa? Journal of Small Business \& Entrepreneurship, 1-27. https://doi.org/10.1080/08276331.2020.1771813

Aghion, P., \& Howitt, P. (1990). A Model of Growth through Creative Destruction (Paper No. 3223). Cambridge, MA: National Bureau of Economic Research. https://doi.org/10.3386/w3223

Aghion, P., Howitt, P., \& Mayer-Foulkes, D. (2005). The Effect of Financial Development on Convergence: Theory and Evidence. The Quarterly Journal of Economics, 120, 173-222. https://doi.org/10.1162/0033553053327515

Ayyagari, M., \& Maksimovic, V. (2007). Firm Innovation in Emerging Markets (Vol. 4157). Washington DC: World Bank Publications.

Ayyagari, M., Demirgüç-Kunt, A., \& Maksimovic, V. (2011). Firm Innovation in Emerging Markets: The Role of Finance, Governance, and Competition. Journal of Financial and Quantitative Analysis, 46, 1545-1580. https://doi.org/10.1017/S0022109011000378

Barasa, L., Knoben, J., Vermeulen, P., Kimuyu, P., \& Kinyanjui, B. (2017). Institutions, 
Resources and Innovation in East Africa: A Firm Level Approach. Research Policy, 46, 280-291. https://doi.org/10.1016/j.respol.2016.11.008

Baumol, W. J. (2002). The Free-Market Innovation Machine: Analyzing the Growth Miracle of Capitalism. Princeton, NJ: Princeton University Press. https://doi.org/10.1515/9781400851638

Brown, F., \& Guzmán, A. (2014). Innovation and Productivity across Mexican Manufacturing Firms. Journal of Technology Management \& Innovation, 9, 36-52. https://doi.org/10.4067/S0718-27242014000400003

Cassoni, A., \& Ramada-Sarasola, M. (2010). Innovation, R\&D Investment and Productivity: Uruguayan Manufacturing Firms (Working Paper No. 65). New York: Inter-American Development Bank. https://doi.org/10.2139/ssrn.1818742

Classen, N., Carree, M., Van Gils, A., \& Peters, B. (2014). Innovation in Family and Non-Family SMEs: An Exploratory Analysis. Small Business Economics, 42, 595-609. https://doi.org/10.1007/s11187-013-9490-Z

Clementi, G. L., \& Hopenhayn, H. A. (2006). A Theory of Financing Constraints and Firm Dynamics. The Quarterly Journal of Economics, 121, 229-265.

https://doi.org/10.1093/qje/121.1.229

Coccia, M. (2018). Optimization in R\&D Intensity and Tax on Corporate Profits for Supporting Labor Productivity of Nations. The Journal of Technology Transfer, 43, 792-814. https://doi.org/10.1007/s10961-017-9572-1

Corbett, C. J., Montes-Sancho, M. J., \& Kirsch, D. A. (2005). The Financial Impact of ISO 9000 Certification in the United States: An Empirical Analysis. Management Science, 51, 1046-1059. https://doi.org/10.1287/mnsc.1040.0358

Crisóstomo, V. L., Iturriaga, F. J. L., \& González, E. V. (2014). Financial Constraints for Investment in Brazil. International Journal of Managerial Finance, 10, 73-92. https://doi.org/10.1108/IJMF-11-2012-0121

Díaz-Chao, Á., Sainz-González, J., \& Torrent-Sellens, J. (2015). ICT, Innovation, and Firm Productivity: New Evidence from Small Local Firms. Journal of Business Research, 68, 1439-1444. https://doi.org/10.1016/j.jbusres.2015.01.030

Fazzari, S. M., \& Petersen, B. C. (1993). Working Capital and Fixed Investment: New Evidence on Financing Constraints. The RAND Journal of Economics, 24, 328-342.

Fernandez, V. (2017). The Finance of Innovation in Latin America. International Review of Financial Analysis, 53, 37-47. https://doi.org/10.1016/j.irfa.2017.08.008

Fudenberg, D., \& Tirole, J. (1983). Capital as a Commitment: Strategic Investment to Deter Mobility. Journal of Economic Theory, 31, 227-250. https://doi.org/10.1016/0022-0531(83)90075-3

Gallego, J. M., Gutiérrez, L. H., \& Taborda, R. (2015). Innovation and Productivity in the Colombian Service and Manufacturing Industries. Emerging Markets Finance and Trade, 51, 612-634. https://doi.org/10.1080/1540496X.2015.1026698

Gorodnichenko, Y., Svejnar, J., \& Terrell, K. (2010). Globalization and Innovation in Emerging Markets. American Economic Journal: Macroeconomics, 2, 194-226. https://www.aeaweb.org/articles?id=10.1257/mac.2.2.194

Hall, B. H. (1992). Investment and Research and Development at the Firm Level: Does the Source of Financing Matter (Working Paper No. 4096)? Cambridge, MA: National Bureau of Economic Research.

Hall, B. H., \& Lerner, J. (2010). The Financing of R\&D and Innovation. In B. H. Hall, \& N. Rosenberg (Eds.), Handbook of the Economics of Innovation (Vol. 1, pp. 609-639). Amsterdam: Elsevier. https://doi.org/10.1016/S0169-7218(10)01014-2 
Janz, N., Lööf, H., \& Peters, B. (2003). Firm Level Innovation and Productivity-Is There a Common Story across Countries (Discussion Paper No. 03-26)? Mannheim: Leibniz Center for European Economic Research. https://doi.org/10.2139/ssrn.416444

Kannebley, S., Sekkel, J. V., \& Araújo, B. C. (2010). Economic Performance of Brazilian Manufacturing Firms: A Counterfactual Analysis of Innovation Impacts. Small Business Economics, 34, 339-353. https://doi.org/10.1007/s11187-008-9118-x

Kirner, E., Kinkel, S., \& Jaeger, A. (2009). Innovation Paths and the Innovation Performance of Low-Technology Firms-An Empirical Analysis of German Industry. Research Policy, 38, 447-458. https://doi.org/10.1016/j.respol.2008.10.011

Lee, K., \& Kang, S.-M. (2007). Innovation Types and Productivity Growth: Evidence from Korean Manufacturing Firms. Global Economic Review, 36, 343-359. https://doi.org/10.1080/12265080701694512

Liu, X. (2015). Applied Ordinal Logistic Regression Using Stata: From Single-Level to Multilevel Modeling. Thousand Oaks, CA: Sage Publications.

Modigliani, F., \& Miller, M. H. (1958). The Cost of Capital, Corporation Finance and the Theory of Investment. The American Economic Review, 48, 261-297.

Nikolov, B., Schmid, L., \& Steri, R. (2021). The Sources of Financing Constraints. Journal of Financial Economics, 139, 478-501. https://doi.org/10.1016/j.jfineco.2020.07.018

Romer, P. M. (1990). Capital, Labor, and Productivity. Brookings Papers on Economic Activity. Microeconomics, 1990, 337-367. https://doi.org/10.2307/2534785

Rosenbaum, P. R., \& Rubin, D. B. (1983). The Central Role of the Propensity Score in Observational Studies for Causal Effects. Biometrika, 70, 41-55. https://doi.org/10.1093/biomet/70.1.41

Solow, R. M. (1957). Technical Change and the Aggregate Production Function. The Review of Economics and Statistics, 39, 312-320. https://doi.org/10.2307/1926047

Wadho, W., \& Chaudhry, A. (2018). Innovation and Firm Performance in Developing Countries: The Case of Pakistani Textile and Apparel Manufacturers. Research Policy, 47, 1283-1294. https://doi.org/10.1016/j.respol.2018.04.007

Wakelin, K. (2001). Productivity Growth and R\&D Expenditure in UK Manufacturing Firms. Research Policy, 30, 1079-1090. https://doi.org/10.1016/S0048-7333(00)00136-0 